\title{
Review: Transplanting kidneys from donors with small renal masses - a strategy to expand the donor pool
}

Octav Cristea, $\mathrm{MD}^{1,2}$; Jeff Warren, $\mathrm{MD}^{1,2}$, Brian Blew, $\mathrm{MD}^{1,2}$, Neal Rowe, $\mathrm{MD}^{1,2}$

${ }^{1}$ Division of Urology, Department of Surgery, The Ottawa Hospital, Ottawa, ON, Canada; ${ }^{2}$ University of Ottawa, Ottawa, ON, Canada

Cite as: Can Urol Assoc J 2019 July 23; Epub ahead of print. http://dx.doi.org/10.5489/cuaj.5926

Published online July 23, 2019

$* * *$

\section{Abstract}

Introduction: Renal transplantation is the optimal treatment for end-stage renal disease, but organ demand continues to outstrip supply. The transplantation of kidneys from donors with small renal masses (SRMs) represents a potential avenue to expand the donor pool. We reviewed all published cases of transplants from donors with SRMs and we present followup data, best practices, and outline an actionable series of steps to guide the implementation of such transplants at individual centres.

Methods: A detailed literature search of the MEDLINE/PubMed and SCOPUS databases was performed. Thirty unique data sets met inclusion criteria and described the transplantation of tumorectomized kidneys; nine data sets described the transplantation of contralateral kidneys from donors with SRMs.

Results: A total of 147 tumorectomized kidneys have been transplanted. Pathology revealed 120 to be renal cell carcinomas (RCCs), of which 116 were stage T1a $(0.3-4 \mathrm{~cm})$. The mean followup time was 44.2 months (1-200 months). A single suspected tumor recurrence occurred in one patient nine years post-transplantation and it was managed with active surveillance. Twenty-seven kidneys have been transplanted from deceased donors with contralateral renal masses. Pathology revealed 25 to be RCCs, of which 19 were confirmed to be stage $\mathrm{T} 1(<7 \mathrm{~cm})$. The mean followup time was 46.7 months (0.5-155 months). One recipient developed an RCC and underwent curative allograft nephrectomy.

Conclusions: Careful use of kidneys from donors with SRMs is feasible and safe, with an overall recurrence rate of less than 1.5\%. The utilization of such kidneys could help alleviate the organ shortage crisis. 


\section{Introduction}

Renal transplantation is considered the gold standard of care for end-stage renal disease (ESRD) and offers significant survival, quality of life, and economic benefits. ${ }^{1-3}$ Despite this, only a minority of patients with ESRD ultimately receive a transplant and organ demand continues to outstrip supply in most developed nations. ${ }^{4-7}$

Multiple strategies have been implemented to increase organ donation and utilization, including increasing living kidney donation, donations after cardiac death (DCD), the use of expanded criteria donor (ECD) kidneys, and national programs to facilitate kidney-paired donations and transplants for highly sensitized patients. ${ }^{8-10}$ In certain regions, system-wide rescue allocation schemes have been implemented in an effort to minimize the discard rate of deceased donor kidneys. ${ }^{11}$ Despite such efforts, more than $15 \%$ of all deceased donor kidneys are discarded. ${ }^{4,6}$ The reasons for discarding a kidney are complex and may include donor, recipient, and organ factors. One potential factor is the incidental discovery of a renal mass at the time of organ procurement or during donor work-up in the case of living donation. The prevalence of incidental renal cell carcinoma (RCC) among cadaveric donors has previously been measured at $0.9 \% .{ }^{12}$ While uncommon, this nevertheless represents the annual loss of hundreds of potentially transplantable kidneys in North America alone.

The oncologic management of small renal masses continues to evolve; nephron-sparing surgery, in the form of partial nephrectomy, is considered to be the standard of care for T1a $(<4 \mathrm{~cm}$, organ confined) renal masses, when technically feasible. ${ }^{13-15}$ A recent US nation-wide analysis assessing the uptake of partial nephrectomy for the treatment of small renal masses between 2009 and 2012 demonstrated rates of $48 \%$ and 33\% in teaching and non-teaching institutions, respectively. ${ }^{16}$ In Canada, a survey of academic centres revealed a partial nephrectomy rate of 78\% for T1a tumours from 1988 to 2014, with an increasing trend over time. ${ }^{17}$ Some small renal masses, therefore, continue to be treated with radical nephrectomy. Often, this may be due to technical factors related to the tumour itself, but a proportion of cases result from patient preference for radical nephrectomy. Such kidneys may represent potentially transplantable organs that would otherwise be discarded.

The potential for safely transplanting kidneys with small renal masses was recognized as early as 1982, when Stubenbord et al. published a case report describing the transplantation of an allograft following removal of a small calcified renal mass, later confirmed to be an RCC. ${ }^{18}$ A number of groups have since published multiple case series describing the transplantation of tumorectomized kidneys from living or deceased donors, as well as kidneys from donors with contralateral renal malignancies. Here, we review and summarize all known cases, to date, of kidneys transplanted from donors with small renal masses, complete with follow-up data. We conclude by outlining a framework for the implementation of a transplant protocol for kidneys recovered from donors with small renal masses, and discuss the potential ethical and logistical pitfalls that may be encountered. 


\section{Methods}

Two authors (N.R. and O.C.) performed a detailed literature search of the MEDLINE/PubMed and SCOPUS databases to identify all published literature describing the transplantation of kidneys from donors with small renal masses. A review of abstracts yielded 39 original studies and case reports, as well as 11 review papers; all of these were individually reviewed. Thirty original publications described the transplantation of tumorectomized kidneys only, 5 described the transplantation of both tumorectomized and contra-lateral kidneys, and 4 describe the transplantation of contra-latral kidneys only. Three publications were excluded from our summary due to insufficient data. Two pairs of studies presented data from the same patient cohorts; in these instances the more recently published and complete data set was used for analysis. Thus, a total of 30 unique data sets describing the transplantation of tumorectomized kidneys were included in our analysis (Table 1), alongside 9 unique data sets describing the transplantation of contra-lateral kidneys from deceased donors with small renal masses (Table 2). Data was extracted using prespecified parameters and included donor type, donor and recipient age, tumour size and pathology, follow-up time and recurrence, follow-up protocol, iummonosuppresion regimen, post-operative graft function, and surgical complications. Any discrepancies or dissagreements that arose during the review and data collection process were resolved by the senior reviewer (N.R.).

\section{Results}

A total of 147 tumorectomized kidneys have been transplanted and included in our summary. Final pathology revealed 120 to be RCCs, 18 to be AMLs, and 9 to be of other benign etiologies. One hundred and thirty (88\%) kidneys came from living donors, the majority of which came from patients undergoing radical nephrectomy for treatment of a renal mass, with the largest such series published by Brook et al. ${ }^{19}$ All of the tumours in the deceased donor kidneys were incidentally discovered. All of the 120 RCCs were stage T1: 116 were T1a $(0.3-4 \mathrm{~cm}), 1$ was T1b $(4.3 \mathrm{~cm})$ and 3 were identified only as T1 $(<7 \mathrm{~cm})$. Pathological subtype was reported as clear cell for 66 (55\%), papillary for 11 (9\%), multilocular/cystic for 3 (3\%), chromophobe for 2 (2\%), and was unspecified or could not be determined for 38 (31\%). Follow-up time was specified for 119 of the RCCs and ranged from 1 to 200 months with a mean of 44.2 months. A single tumour recurrence was documented in a 71-year-old male 9 years post-transplant and was characterized by a $1 \mathrm{~cm}$ lesion in the allograft, remote from the original tumour site. The patient opted for active surveillance and, at the time of study publication, the lesion had increased by $0.2 \mathrm{~cm}$ over an 18 -month observation period. $^{19}$

The presence or absence of post-operative complications was specifically commented on in 22 of the 30 data sets, accounting for 112 of the tumorectomized kidneys. Among these, there were 5 (4.5\%) instances of urine leak, all of which were sucessfuly manged conservatively; 2 (1.8\%) instances of bleeding requiring re-operation; and 2 (1.8\%) instances of an AV fistula or pseudoaneurysm requiring angioembolization. ${ }^{18-21}$ One-year graft survival could be determined for 129 of the tumorectomized kidneys and was 95\%. 
A total of 27 kidneys have been transplanted from deceased donors with contra-lateral renal masses; of these, final pathology confirmed 25 as RCCs, 1 as a tubulo-papillary adenoma and 1 as an oncocytoma. Amongst the RCCs, 19 were stage T1, while the stage was unspecified in 6 cases. Follow-up time was reported for 24 of the RCCs and ranged from 0.5-155 months with a mean of 46.7 months. One kidney in this group was removed 3 months post-transplant due to nonsalvageable acute rejection. This patient subsequently died 75 months after the original transplant from a confirmed de-novo renal cancer of his native kidneys, which was deemed unrelated to the transplanted kidney. ${ }^{22}$ The patient who received a kidney from a donor with a contralateral $1.7 \mathrm{~cm}$ tubulo-papillary adenoma underwent a biopsy at 4 months to rule-out rejection; this demonstrated diffuse and poorly differentiated RCC and imaging revealed enlarged adjacent lymph nodes. He subsequently underwent allograft nephrectomy and was monitored for 2 years before receiving a second transplant; three years after his second transplant he remained free of disease. ${ }^{23}$ Of note, in this particular case, the recipient of the original donor heart succumbed to metastatic RCC 7 months post-transplant, suggesting circulating cancer cells at the time of organ procurement.

\section{Discussion}

It is well known that solid organ transplantation increases the overall risk of malignancy in transplant recipients, most likely as a consequence of the post-transplant immunosuppressed state. ${ }^{24,25}$ However, there is no evidence to suggest that immunosuppression has a negative impact on the natural history of localized RCC. Reflecting this, multiple existing clinical guidelines suggest that patients with small $(<5 \mathrm{~cm})$, incidentally discovered RCCs need not delay renal transplantation after undergoing surgical treatment, given the low risk of recurrence. ${ }^{26,27}$

The results of the aforementioned studies suggest that transplantation of tumorectomized kidneys is similarly safe and feasible, with only 1 suspected tumour recurrence demonstrated to date. The data supporting the transplantation of contralateral kidneys is more limited. However, the risk of concomitant metastatic disease for T1a renal masses is $<2 \%$ and contralateral kidneys in this setting are therefore expected to be low risk for disease transmission with transplantation. To date, one case of recurrence has been described and occurred in a manner suggesting the presence of circulating cancer cells and/or micrometastases at the time of organ procurement. Taken together, the entire data set herein presented demonstrates a $1.4 \%$ recurrence rate amongst recipients of tumorectomized and contra-lateral kidneys from donors with confirmed small RCCs. This rate is comparable to that described in the literature for small renal masses treated with partial nephrectomy. ${ }^{28}$

While not without risk, the small risk of RCC recurrence needs to be weighed against the risk of remaining on dialysis. In their analysis of 43 patients who received tumorectomized kidneys, Brook et al. demonstrated an increased 4-year survival rate over dialysis patients remaining on the waiting-list; survival was comparable to recipients of living unrelated kidneys matched for age, gender and HLA mismatch. ${ }^{19}$ Not all kidney transplant candidates would be willing to receive a kidney from a donor with a small renal mass and, indeed, only a subset of patients would be suitable 
recipients. One survey of patients on a transplant list in northern England, however, revealed that 59\% would support the use of such kidneys. ${ }^{29}$

We propose that judicious use of such kidneys in carefully selected patients is warranted and may serve as a reasonable and readily implementable strategy for combating the growing organ shortage crisis. To guide the implementation of such an effort, we outline a number of key considerations based on best practices from the studies hitherto published in the literature. A robust discussion of the ethical implications of transplanting kidneys with small renal masses is presented by Flechner and Campbell ${ }^{30}$ and serves as a valuable adjunct to the considerations herein presented.

\section{Ethical and legal approval}

For any institution interested in transplanting kidneys from donors with small renal masses, we recommend an initial consultation with their respective Ethics and Legal departments. The objective is to review proposed protocols and supporting evidence, such that no transplant program risks running afoul of the ethical and legal criteria pertinent to their particular centre.

\section{Recipient selection and counselling}

Patients being newly listed or currently on the transplant wait-list should receive counselling about the potential of receiving a kidney from a donor with a small renal mass. The consent discussion must clearly outline the risk of cancer recurrence and transmission, including the possibility of death from metastatic disease, as well as the risk of surgical complications related to the tumour excision. Specific surgical risks such as bleeding, urine leak and arterio-venous fistula should be discussed. Patients should be informed about the need for ongoing post-transplant surveillance for RCC recurrence, in addition to the standard post-transplant follow-up. We propose that this informed process be conducted in a similar fashion and time as that performed for consideration of ECD and DCD kidneys. Consideration should also be given to establishing a well-defined set of eligibility criteria. In their series, Brook et al. limited potential recipients to those older than 60 years of age, with significant co-morbidities, difficulties with vascular access, and/or an expected mortality rate of $>50 \%$ within 3-4 years. ${ }^{19}$ While there is insufficient data to determine an optimal set of recipient criteria, we recommend that both patient life expectancy as well as expected waitlist time be taken into consideration when formulating such criteria. We also recognize that these criteria will, and likely should, differ between individual transplant centres.

\section{Donor counselling}

In all patients found to harbour an incidentally discovered small renal mass, a referral should be sent to a urologist for consideration of nephron-sparing surgery. The patient should be counselled about all currently accepted management options including active surveillance, ablative therapies, nephron-sparing surgery and radical nephrectomy. It is imperative that these patients be counselled primarily from the standpoint of oncologic control and preservation of renal function and not as potential kidney donors. Failure to adopt this mindset may jeopardize patient care, compromise trust in the transplant community, and expose those involved in their care to ethical and legal ramifications. It is our recommendation that the subject of kidney donation not be raised until the 
decision to proceed with radical nephrectomy has been independently made and well documented. Furthermore, it is important that the process be expedited so as not to cause any unnecessary delay in definitive treatment of the tumour. We recommend that the transplant surgeon not be involved in the final decision about tumour management so as to avoid any potential conflict of interest. Likewise, patients being evaluated for living kidney donation who are found to have an incidental renal mass should be referred to a urologist for a full discussion about the appropriate oncologic management of small renal masses. Only once this discussion has been completed should living donation be entertained, provided both donor and recipient still wish to pursue this course of action.

\section{Donor workup and investigations}

All potential living donors found to have a small renal mass should undergo full clinical and radiographic evaluation including history, physical exam, abdominal CT, chest x-ray and laboratory investigations. It is important that such patients be counselled about the risk of metachronous tumours of the contralateral kidney, which can occur in up to $0.8 \%$ of cases. ${ }^{31}$ This figure may be higher if a papillary subtype of RCC is confirmed on final pathology. When appropriate, clinicians should screen patients for genetic syndromes that are associated with an increased risk of renal tumours, such as Von Hippel-Lindau or Tuberous Sclerosis Complex. Genetic testing should be offered to these patients and their families when indicated. Finally, a differential renal scan should be considered in all donors to ensure adequate nephron function in the contra-lateral kidney prior to undergoing radical nephrectomy.

Deceased donors with incidentally discovered renal tumours should undergo careful intraoperative assessment to rule out the presence of metastatic disease, including sternotomy and inspection of the thoracic organs. In their series, Pandanaboyana et al. used back-table ultrasound to inspected all contra-lateral kidneys and rule out the presence of a synchronous or metastatic tumour. ${ }^{32}$ The families of deceased donors with small incidentally discovered masses should be informed about the findings, and potential recipients of other organs from the same donor should be counselled accordingly.

We recommend that only kidneys from donors with T1a tumours ( $<4 \mathrm{~cm}$; organ confined) be considered for transplantation. At the time of organ procurement, a sample of tissue can be sent for frozen section analysis at the discretion of the transplant surgeon; while this should reliably confirm the diagnosis, recently published data casts doubt on its utility in accurately predicting surgical margins and changing management. ${ }^{33}$

\section{Immunosuppression}

Contemporary immunosuppression in kidney transplant recipients most commonly consists of a calcineurin inhibitor (CNI), an anti-proliferative agent and a systemic corticosteroid. Mammalian target of rapamycin (mTOR) inhibitors, such as sirolimus, are alternate maintenance agents for CNIs and are used most commonly in the setting of refractory CNI toxicity. ${ }^{34}$ These drugs have well characterized anti-neoplastic properties; everolimus, for example, is currently approved for treatment of metastatic RCC. ${ }^{35}$ In the transplant setting, the use of sirolimus has been associated with a decreased incidence of renal and cutaneous malignancies, but an increased risk of prostate 
cancer. ${ }^{36}$ Instances of tumour regression after conversion to mTOR inhibitors have also been reported in some de-novo post-transplant malignancies; however, data for the regression of solid tumours is limited. ${ }^{37}$ In the reviewed data series presented, 5 studies used an mTOR inhibitor in their maintenance immunosuppression regimen as a matter of course, accounting for 34

patients. $^{20,21,38-40}$ Based on the published literature, it is unclear if the use of mTOR inhibitors would reduce the risk of RCC recurrence, and a definitive recommendation cannot be made at this time.

\section{Followup protocol}

There is no universally established follow-up regimen for patients with small, localized renal malignancies. ${ }^{28}$ Among the studies herein reviewed, 8 specified a follow-up protocol. The frequency of imaging ranged from every 3 to 12 months and included a combination of ultrasound, chest $\mathrm{x}$-ray and CT scans. In the absence of definitive guidelines, we recommend a conservative approach comprised of ultrasound, chest x-ray, abdominal CT, and laboratory investigations (CBC, BMP, LFTs including ALP, and Calcium) as outlined in Table 3.

\section{Data collection and monitoring}

At centres instituting a practice of transplanting kidneys from donors with small renal masses we recommend a well-defined patient roster for the purposes of tracking patient outcomes. Patients discharged back to the care of their primary care physicians should be instructed to report any suspected tumour recurrence to the original transplant centre.

\section{Limitations}

Our review has several limitations. Much of the available data has been published in the form of case reports or small case series, and there exists a risk of publication bias. There is some heterogeneity of the data, making detailed comparisons or statistical analysis difficult. The followup data presented was generally limited to the medium-term, with only a few long-term cases. Nevertheless, the very low rate of recurrence in this setting is still reassuring and suggests that the oncologic risk is not significantly affected by the immunosuppresed state. 


\section{Conclusions}

Kidneys recovered and restored from donors with small renal masses are often suitable for subsequent transplantation. Post-transplant immunosuppression does not appear to alter the natural history of localized RCC; observed recurrence rates are minimal and in keeping with those expected from small renal masses in non-transplant patients. To the best of our knowledge, this review represents the most comprehensive summary of such cases to date. Potential recipients should be carefully selected and extensively counselled about the potential use of such kidneys; a rigorous informed consent process is necessary for both living donors and any intended recipients. We argue that the existing data supports judicious use of such kidneys to expand the donor pool and help alleviate the current organ shortage. Centres that implement the use of these transplants should do so in a structured and protocolized manner, and long-term follow-up should be instituted to monitor for recurrence. 


\section{References}

1. Wolfe RA, Ashby VB, Milford EL, et al. Comparison of mortality in all patients on dialysis, patients on dialysis awaiting transplantation, and recipients of a first cadaveric transplant. $N$ Engl J Med 1999;341(23):1725-30.

2. Wong G, Howard K, Chapman JR, et al. Comparative survival and economic benefits of deceased donor kidney transplantation and dialysis in people with varying ages and comorbidities. PloS one 2012;7(1):e29591.

3. Tonelli M, Wiebe N, Knoll G, et al. Systematic review: kidney transplantation compared with dialysis in clinically relevant outcomes. Am J Transplant 2011;11(10):2093-109.

4. Klein AS, Messersmith EE, Ratner LE, et al. Organ donation and utilization in the United States, 1999-2008. Am J Transplant 2010;10(4 Pt 2):973-86.

5. Norris S. Organ Donation and Transplantation in Canada. In: Service PIaR, editor. Ottawa, Ontario, Canada: Library of Parliament; 2014.

6. Samuel U. Annual Report of the Eurotransplant International Foundation. Leiden, The Netherlands: Eurotransplant International Foundation, 2014.

7. Johnson RJ, Bradbury LL, Martin K, et al. Organ donation and transplantation in the UK-the last decade: a report from the UK national transplant registry. Transplantation 2014;97 Suppl 1:S1-s27.

8. Rose C, Schaeffner E, Frei U, et al. A Lifetime of Allograft Function with Kidneys from Older Donors. J Am Soc Nephrol 2015;26(10):2483-93.

9. Summers DM, Watson CJ, Pettigrew GJ, et al. Kidney donation after circulatory death (DCD): state of the art. Kidney Int 2015;88(2):241-9.

10. Knoll GA, Tinckam KJ. Organ Donation and Transplantation: The View From Canada. Transplantation 2015;99(11):2231-3.

11. Vinkers MT, Smits JM, Tieken IC, et al. Kidney donation and transplantation in Eurotransplant 2006-2007: minimizing discard rates by using a rescue allocation policy. Progress in transplantation 2009;19(4):365-70.

12. Carver BS, Zibari GB, McBride V, et al. The incidence and implications of renal cell carcinoma in cadaveric renal transplants at the time of organ recovery. Transplantation 1999;67(11):1438-40.

13. Van Poppel H, Becker F, Cadeddu JA, et al. Treatment of localised renal cell carcinoma. Eur Urol 2011;60(4):662-72.

14. MacLennan S, Imamura M, Lapitan MC, et al. Systematic review of oncological outcomes following surgical management of localised renal cancer. Eur Urol 2012;61(5):972-93.

15. MacLennan S, Imamura M, Lapitan MC, et al. Systematic review of perioperative and quality-of-life outcomes following surgical management of localised renal cancer. Eur Urol 2012;62(6):1097-117.

16. Vigneswaran HT, Lec P, Brito J, Turini G, Pareek G, Golijanin D. Partial Nephrectomy for Small Renal Masses: Do Teaching and Nonteaching Institutions Adhere to Guidelines Equally? Jour Endourol 2016;30(6):714-21.

17. Lavallee LT, Tanguay S, Jewett MA, et al. Surgical management of stage T1 renal tumours at Canadian academic centres. Can Urol Assoc J 2015;9(3-4):99-106. 
18. Stubenbord WT, Cheigh JS, Riggio RR. Kidney transplantation immediately following excision of a malignant tumor from the donor kidney: a case report with long-term followup. Transplant Proc 1982;14(4):775-6.

19. Brook NR, Gibbons N, Johnson DW, et al. Outcomes of transplants from patients with small renal tumours, live unrelated donors and dialysis wait-listed patients. Transpl Int 2010;23(5):476-83.

20. Musquera M, Perez M, Peri L, et al. Kidneys from donors with incidental renal tumors: should they be considered acceptable option for transplantation? Transplantation 2013;95(9):1129-33.

21. He B, Mitchell A, Lim W, Delriviere L. Restored kidney graft from urologist referrals for renal transplantation. Transplant Proc 2013;45(4):1343-6.

22. Penn I. Primary kidney tumors before and after renal transplantation. Transplantation 1995;59(4):480-5.

23. Barrou B, Bitker MO, Delcourt A, et al. Fate of a renal tubulopapillary adenoma transmitted by an organ donor. Transplantation 2001;72(3):540-1.

24. Vajdic CM, McDonald SP, McCredie MR, et al. Cancer incidence before and after kidney transplantation. JAMA 2006;296(23):2823-31.

25. Acuna SA, Fernandes KA, Daly C, et al. Cancer Mortality Among Recipients of SolidOrgan Transplantation in Ontario, Canada. JAMA Oncol. 2016:1-8.

26. Kasiske BL, Cangro CB, Hariharan S, et al. The evaluation of renal transplantation candidates: clinical practice guidelines. Am J Transplant 2001;1 S: 2:3-95.

27. Knoll G, Cockfield S, Blydt-Hansen T, et al. Canadian Society of Transplantation consensus guidelines on eligibility for kidney transplantation. CMAJ 2005;173(10):1181-4.

28. Donat SM, Diaz M, Bishoff JT, et al. Follow-up for Clinically Localized Renal Neoplasms: AUA Guideline. J Urol 2013;190(2):407-16.

29. Khurram MA, Sanni AO, Rix D, Talbot D. Renal transplantation with kidneys affected by tumours. Int J Nephrol 2011;2010:529080.

30. Flechner SM, Campbell SC. The use of kidneys with small renal tumors for transplantation: who is taking the risk? Am J Transplant 2012;12(1):48-54.

31. Wiklund F, Tretli S, Choueiri TK. Risk of bilateral renal cell cancer. JCO 2009;27(23):3737-41.

32. Pandanaboyana S, Longbotham D, Hostert L, et al. Transplantation of liver and kidney from donors with malignancy at the time of donation: an experience from a single centre. Transpl Int 2016;29(1):73-80.

33. Gordetsky J, Gorin MA, Canner J, et al. Frozen section during partial nephrectomy: does it predict positive margins? BJU Int 2015;116(6):868-72.

34. Schena FP, Pascoe MD, Alberu J, et al. Conversion from calcineurin inhibitors to sirolimus maintenance therapy in renal allograft recipients: 24-month efficacy and safety results from the CONVERT trial. Transplantation 2009;87(2):233-42.

35. Motzer RJ, Escudier B, Oudard S, et al. Efficacy of everolimus in advanced renal cell carcinoma: a double-blind, randomised, placebo-controlled phase III trial. Lancet 2008;372(9637):449-56.

36. Yanik EL, Siddiqui K, Engels EA. Sirolimus effects on cancer incidence after kidney transplantation: a meta-analysis. Cancer Med 2015;4(9):1448-59. 
37. Monaco AP. The role of mTOR inhibitors in the management of posttransplant malignancy. Transplantation 2009;87(2):157-63.

38. Dainys B, Rainiene T, Vareikiene L, Kucinskis G. Living donor kidney transplantation after resection of carcinoma. Medicina 2007;43 Suppl 1:145-7.

39. Melgosa Hijosa M, Alonso Melgar A, et al. Living-donor transplantation after excision of unrecognized renal cancer diagnosed after transplant. Pediatr Nephrol 2012;27(12):2319-21.

40. Lim SY, Kim MG, Park KT, et al. Experiences of renal transplants from donors with renal cell carcinoma after ex vivo partial nephrectomy. Ann Surg Treat Res 2017;92(5):361-4.

41. Wang X, Zhang X, Men T, et al. Kidneys With Small Renal Cell Carcinoma Used in Transplantation After Ex Vivo Partial Nephrectomy. Transplant Proc 2018;50(1):48-52.

42. Nyame YA, Babbar P, Aboumohamed AA, et al. Ex-vivo partial nephrectomy after living donor nephrectomy: Surgical technique for expanding kidney donor pool. Urol Ann 2017;9(1):107-9.

43. McGregor TB, Rampersad C, Patel P. Expanding living kidney donor criteria with ex-vivo surgery for renal anomalies. Can Urol Assoc J 2016;10(9-10):301-5.

44. Ogawa Y, Kojima K, Mannami R, et al. Transplantation of Restored Kidneys From Unrelated Donors After Resection of Renal Cell Carcinoma: Results From 10 Patients. Transplant Proc 2015;47(6):1711-9.

45. Lugo-Baruqui JA, Guerra G, Chen L, et al. Living donor renal transplantation with incidental renal cell carcinoma from donor allograft. Transpl Int 2015;28(9):1126-30.

46. Khurana K, Modlin C. Intraoperative management of renal allograft venous-calyceal fistula and incidental renal cell carcinoma during renal transplantation: a case report. Transplant Proc 2013;45(9):3421-3.

47. Singh J, Gupta A, Nadar D, Singhal M. Kidney transplantation after ex vivo excision of an angiomyolipoma from a living related kidney donor. Indian J Transplant 2013;7(4):117-9.

48. Valente M, Furian L, Rigotti P. Organ donors with small renal cancer: report of 3 cases. Transplant Proc. 2012;44(7):1846-7.

49. Abboudi $\mathrm{H}$, Chandak $\mathrm{P}$, Kessaris $\mathrm{N}$ et al. A successful live donor kidney transplantation after large angiomyolipoma excision. Int J Surg Case Rep 2012;3(12):594-6.

50. Ali AM, Rajagoppal P, Sayed A, et al. Transplant of kidneys with small renal cell carcinoma in incompatible, heavily immunosuppressed recipients. Ann R Coll Surg Engl 2012;94(6):e189-90.

51. Meyyappan RM, Rajaraman T, Senthil D. Incidental solid renal mass in a cadaveric donor kidney. Indian J Urol 2012;28(2):202-3.

52. Nicol DL, Preston JM, Wall DR, et al. Kidneys from patients with small renal tumours: a novel source of kidneys for transplantation. BJU Int 2008;102(2):188-92; discussion 92-3.

53. Bycroft JA, Benaragama KS, Green A, et al. Incidental renal cell carcinoma identified during laparoscopic live-related donor nephrectomy. JRSM short reports 2010;1(4):32.

54. Sener A, Uberoi V, Bartlett ST, et al. Living-donor renal transplantation of grafts with incidental renal masses after ex-vivo partial nephrectomy. BJU Int 2009;104(11):1655-60.

55. Mannami M, Mannami R, Mitsuhata N, et al. Last resort for renal transplant recipients, 'restored kidneys' from living donors/patients. Am J Transplant 2008;8(4):811-8.

56. Johannes JR, Doria C, Lallas CD. In vivo partial nephrectomy of angiomyolipoma with concurrent transplantation. Can Urol Assoc J 2008;15(4):4184-7. 
57. Ghafari A. Transplantation of a kidney with a renal cell carcinoma after living donation: a case report. Transplant Proc 2007;39(5):1660-1.

58. Buell JF, Hanaway MJ, Thomas M, et al. Donor kidneys with small renal cell cancers: can they be transplanted? Transplant Proc 2005;37(2):581-2.

59. Hetet JF, Rigaud J, Blancho G. Renal transplantation after excision of an angiomyolipoma on living donor kidney. Progres en urologie 2004;14(2):205-6.

60. Lasaponara F, Catti M, Ferraris C. Nephron-sparing treatment of kidney neoplasms in transplanted kidney. Our experience. Minerva urologica e nefrologica 2000;52(4):179-81.

61. Chen A, Scherr D, Eid JF. Renal transplantation after in vivo excision of an angiomyolipoma from a living unrelated kidney donor. J Urol 2000;163(6):1859.

62. Weiss SG, Hafez RG, Uehling DT. Multiocular cystic renal cell carcinoma: implications for nephron sparing surgery. Urology 1998;51(4):635-7.

63. Bissada NK, Bissada SA, Fitts CT, et al. Renal transplantation from living related donor after excision of angiomyolipoma of the donor kidney. $J$ Urol 1993;150(1):174-5.

64. Moris D, Dounousi E, Zavos G. Donor-origin cancer in renal transplant recipients from deceased donors: worth gambling? Transpl Int 2015;28(2):253-4.

65. Carver BS, Zibari GB, Venable DD, et al. Renal cell carcinoma detected in a cadaveric donor after orthotopic liver and contralateral renal transplantation in two recipients: fouryear follow-up. Transplantation 2001;71(9):1348-9.

66. Pliskin MJ, Soderdahl DW, Jones R. Renal cell carcinoma in cadaver donor kidney. Urology 1988;32(4):345-6.

67. Hozo SP, Djulbegovic B, Hozo I. Estimating the mean and variance from the median, range, and the size of a sample. BMC Med Res Methodol. 2005;5(13). 
Figures and Tables

\begin{tabular}{|c|c|c|c|c|c|c|c|}
\hline Publication & Location & $\begin{array}{l}\text { Donor } \\
\text { type }\end{array}$ & Pathology & $\begin{array}{l}\text { Tumor } \\
\text { size, } \\
\text { cm } \\
\text { (mean) }\end{array}$ & $\begin{array}{l}\text { Recipient } \\
\text { Age, } \\
\text { yr (mean) }\end{array}$ & $\begin{array}{c}\text { Followup, } \\
\text { mo. } \\
\text { (mean) }\end{array}$ & Recurrence \\
\hline Wang $2018^{41}$ & China & Living & 7 RCC & $\begin{array}{c}2.1-3.5 \\
(2.8)\end{array}$ & 29-57 (46.9) & $\begin{array}{l}31-58 \\
(39.9) \\
\end{array}$ & None \\
\hline $\operatorname{Lim} 2017^{40}$ & $\begin{array}{l}\text { South } \\
\text { Korea }\end{array}$ & Living & 2 RCC & $0.9,0.7$ & 52,34 & $>32$ & None \\
\hline Nyame $2017^{42}$ & USA & Living & $1 \mathrm{AML}$ & 2.6 & Not specified & 24 & None \\
\hline $\begin{array}{l}\text { Pandanaboyan } \\
\text { a } 2016^{32}\end{array}$ & UK & Deceased & $3 \mathrm{RCC}$ & $<7$ & $3-63(40)$ & $12-51(33)$ & None \\
\hline $\begin{array}{l}\text { McGregor } \\
2016^{43}\end{array}$ & Canada & Living & $1 \mathrm{AML}$ & $2.2 \mathrm{~cm}$ & Not specified & 12 & None \\
\hline Ogawa $2015^{44}$ & Japan & Living & $10 \mathrm{RCC}$ & $\begin{array}{c}1.5-3.9 \\
(3.1)\end{array}$ & 46-66 (56.1) & $\begin{array}{l}32-58 \\
(46.1)\end{array}$ & None \\
\hline $\begin{array}{l}\text { Lugo-Baruqui } \\
2015^{45}\end{array}$ & USA & Living & 4 RCC & $\begin{array}{c}0.9-2.5 \\
(1.4)\end{array}$ & 20-79 (57.1) & 36 & None \\
\hline $\begin{array}{l}* \text { Musquera } \\
2013^{20}\end{array}$ & Spain & $\begin{array}{c}\text { Living \& } \\
\text { Deceased } \\
(4 ; 4)\end{array}$ & $\begin{array}{c}7 \text { RCC } \\
1 \text { lipoma }\end{array}$ & $\begin{array}{c}0.3-4.3 \\
(1.5) \\
1.4\end{array}$ & $38-73(53.4)$ & $\begin{array}{c}1-57 \\
(32.3)\end{array}$ & None \\
\hline He $2013^{21}$ & Australia & Living & $\begin{array}{l}20 \mathrm{RCC} \\
1 \mathrm{AML}\end{array}$ & $\begin{array}{c}1.7-3.3 \\
(2.5)\end{array}$ & 49-80 (66.3) & $\begin{array}{c}6-55 \\
(28.3)^{\varepsilon}\end{array}$ & None \\
\hline $\begin{array}{l}\text { Khurana } \\
2013^{46}\end{array}$ & USA & Deceased & $1 \mathrm{RCC}$ & 0.7 & 58 & 8 & None \\
\hline Singh $2013^{47}$ & India & Living & $1 \mathrm{AML}$ & 4.3 & Not specified & 1 & None \\
\hline Valente $2012^{48}$ & Italy & Deceased & $1 \mathrm{RCC}$ & 0.8 & 39 & 52 & None \\
\hline $\begin{array}{l}\text { Abboudi } \\
2012^{49}\end{array}$ & $\begin{array}{c}\text { Netherlan } \\
\text { ds }\end{array}$ & Living & $1 \mathrm{AML}$ & 7 & 54 & 36 & None \\
\hline Ali $2012^{50}$ & UK & Living & 2 RCC & $0.5,1.4$ & 57,51 & 48,72 & None \\
\hline $\begin{array}{l}\text { Melgosa } \\
\text { Hijosa } 2012^{39}\end{array}$ & Spain & Living & $1 \mathrm{RCC}$ & 2.5 & 3 & 96 & None \\
\hline $\begin{array}{l}\text { Meyyappan } \\
2012^{51}\end{array}$ & India & Deceased & 1 RMICT & 2 & 36 & 3 & None \\
\hline $\begin{array}{l}{ }^{\delta} \text { Brook } 2010^{19} \\
\& \\
\text { Nicoll } 2008^{52}\end{array}$ & Australia & $\begin{array}{c}\text { Living \& } \\
\text { Deceased } \\
(38 ; 3)\end{array}$ & $\begin{array}{c}31 \text { RCC } \\
5 \text { AML } \\
3 \text { complex } \\
\text { cysts } \\
2 \\
\text { oncocyto } \\
\text { mas }\end{array}$ & $\begin{array}{l}1-2.9 \\
(2.2)\end{array}$ & (60.9) & (32) & $\begin{array}{c}1 \text { suspected } \\
\text { (108 mo.) }\end{array}$ \\
\hline
\end{tabular}


Transplanting kidneys from donors with small renal masses

\begin{tabular}{|c|c|c|c|c|c|c|c|}
\hline Bycroft $2010^{53}$ & UK & Living & 1 RCC & 0.7 & 49 & $\begin{array}{c}\text { Not } \\
\text { specified }\end{array}$ & Not specified \\
\hline Sener $2009^{54}$ & USA & Living & $\begin{array}{l}3 \mathrm{RCC} \\
2 \mathrm{AML}\end{array}$ & $\begin{array}{c}1.0-2.2 \\
(1.6) \\
1.1,2.3 \\
\end{array}$ & $\begin{array}{c}47-56(51) \\
58,61\end{array}$ & $\begin{array}{c}9-31 \\
(18.3) \\
1,41 \\
\end{array}$ & $\begin{array}{l}\text { None } \\
\text { None }\end{array}$ \\
\hline $\begin{array}{l}\text { Manami } \\
2008^{55}\end{array}$ & Japan & Living & $\begin{array}{c}8 \text { RCC } \\
2 \text { AML } \\
1 \\
\text { cavernous } \\
\text { angioma } \\
1 \text { calcified } \\
\text { cyst } \\
\end{array}$ & $\begin{array}{c}1.2-3.5 \\
(2.4) \\
3.5,-- \\
2.5 \\
\\
--\end{array}$ & $\begin{array}{c}28-69(50.8) \\
56,47 \\
48 \\
67\end{array}$ & $\begin{array}{c}3-145 \\
(52.3) \\
107,16 \\
90 \\
13\end{array}$ & $\begin{array}{l}\text { None } \\
\text { None } \\
\text { None } \\
\text { None }\end{array}$ \\
\hline $\begin{array}{l}\text { Johannes } \\
2008^{56}\end{array}$ & USA & Living & $1 \mathrm{AML}$ & 1.5 & 55 & 18 & None \\
\hline Ghafari $2007^{57}$ & Iran & Living & $1 \mathrm{RCC}$ & 0.5 & 12 & 15 & None \\
\hline Dainys $2007^{38}$ & Lithuania & Living & $1 \mathrm{RCC}$ & 2 & 38 & $>72$ & None \\
\hline $\begin{array}{l}\text { Buell } 2005^{58} \& \\
\text { Penn } 1995^{22}\end{array}$ & USA & $\begin{array}{c}\text { Living \& } \\
\text { Deceased } \\
(11 ; 3) \\
\end{array}$ & 14 RCC & $\begin{array}{l}0.5-4 \\
(2.1)^{\varepsilon}\end{array}$ & $(40.8)$ & $\begin{array}{c}14-200 \\
(88)^{\varepsilon}\end{array}$ & None \\
\hline Hetet $2004^{59}$ & France & Living & $1 \mathrm{AML}$ & 0.7 & 29 & 24 & None \\
\hline $\begin{array}{l}\text { Lasaponara } \\
2000^{60}\end{array}$ & Italy & Living & $1 \mathrm{RCC}$ & 1 & Not specified & 138 & None \\
\hline Chen $2000^{61}$ & USA & Living & $1 \mathrm{AML}$ & & 62 & $\begin{array}{c}\text { Not } \\
\text { specified }\end{array}$ & None \\
\hline Weiss $1998^{62}$ & USA & Living & $1 \mathrm{RCC}$ & 1 & 45 & 120 & None \\
\hline Bissada $1993^{63}$ & USA & Living & $1 \mathrm{AML}$ & 3 & 44 & 2 & None \\
\hline $\begin{array}{l}\text { Stubenbord198 } \\
2^{18}\end{array}$ & USA & Deceased & 1 RCC & 3 & Not specified & 96 & None \\
\hline
\end{tabular}

*Tumor size and followup time provided for entire cohort of 10 patients as a whole, which includes two patients who received contra-lateral kidneys from Table $2{ }^{\delta}$ Average recipient age and followup time provided for entire cohort of 43 patients as a whole, which includes two patients who received contralateral kidneys from Table $2 .{ }^{8}$ In these instances medians, accompanied by minimum and maximum values, were reported by the authors. We provide here an estimated mean for the cohort in question, calculated using techniques available in the published literature, in order to allow for a comparison across studies. ${ }^{67}$ AML: angiomyolipoma; RCC: renal cell carcinoma. 


\begin{tabular}{|c|c|c|c|c|c|c|c|}
\hline Publication & Location & $\begin{array}{l}\text { Donor } \\
\text { type }\end{array}$ & Pathology & $\begin{array}{l}\text { Tumor } \\
\text { size, } \\
\text { cm } \\
\text { (mean) }\end{array}$ & $\begin{array}{l}\text { Recipient } \\
\text { age, } \\
\text { yr (mean) }\end{array}$ & $\begin{array}{l}\text { Followup, } \\
\text { mo. (mean) }\end{array}$ & Recurrence \\
\hline $\begin{array}{l}\text { Pandanaboyan } \\
\text { a et al, } 2016^{18}\end{array}$ & UK & Deceased & $\begin{array}{c}2 \text { RCC } \\
1 \\
\text { oncocytoma }\end{array}$ & $<7$ & $\begin{array}{c}41,56 \\
48\end{array}$ & $\begin{array}{c}24,25 \\
64\end{array}$ & $\begin{array}{c}\text { None } \\
--\end{array}$ \\
\hline $\begin{array}{l}\text { Morris et al, } \\
2015^{64}\end{array}$ & Greece & Deceased & $1 \mathrm{RCC}$ & 2.5 & $\begin{array}{c}\text { Not } \\
\text { specified }\end{array}$ & 48 & None \\
\hline $\begin{array}{l}\text { *Musquera et } \\
\text { al, } 2013^{20}\end{array}$ & Spain & Deceased & 2 RCC & $\begin{array}{c}0.3-4.3 \\
(1.5)\end{array}$ & 54,57 & $1-57$ (32.3) & None \\
\hline $\begin{array}{l}\text { Valente et al, } \\
2012^{48}\end{array}$ & Italy & Deceased & 2 RCC & $0.2,1.5$ & 45,50 & 22,56 & None \\
\hline $\begin{array}{l}{ }^{\delta} \text { Brook et al, } \\
2010^{19} \& \\
\text { Nicoll et al, } \\
2008^{52}\end{array}$ & Australia & Deceased & 2 RCC & $1-2.9(2.2)$ & (60.9) & (32) & None \\
\hline $\begin{array}{l}\text { Barrou et al, } \\
2001^{23}\end{array}$ & France & Deceased & $\begin{array}{l}1 \text { tubulo- } \\
\text { papillary } \\
\text { adenoma }\end{array}$ & 1.7 & 63 & 4 & $\begin{array}{c}1 \text { confirmed } \\
(4 \text { mo. })\end{array}$ \\
\hline $\begin{array}{l}\text { Carver et al, } \\
2001^{65}\end{array}$ & USA & Deceased & $1 \mathrm{RCC}$ & 1.0 & 65 & 48 & None \\
\hline Penn, $1995^{22}$ & USA & Deceased & 14 RCC & $\begin{array}{l}\leq 4 \mathrm{~cm} \text { in } 7 \\
\text { unknown } \\
\text { in } 7\end{array}$ & $\begin{array}{c}\text { Not } \\
\text { specified }\end{array}$ & $\begin{array}{l}0.5-155 \\
\quad(55)\end{array}$ & None \\
\hline $\begin{array}{l}\text { Pliskin et al, } \\
1998^{66}\end{array}$ & USA & Deceased & $1 \mathrm{RCC}$ & 2.7 & 46 & $\begin{array}{c}\text { Not } \\
\text { specified }\end{array}$ & $\begin{array}{c}\text { Not } \\
\text { specified }\end{array}$ \\
\hline
\end{tabular}

*Tumor size and followup time provided for entire cohort of 10 patients as a whole, which includes 8 patients who received tumorectomized kidneys from Table $1 .{ }^{\delta}$ Average recipient age and followup time provided for entire cohort of 43 patients as a whole, which includes 41 patients who received tumorectomized kidneys from Table 1. RCC: renal cell carcinoma. 


\begin{tabular}{|c|c|}
\hline $\begin{array}{l}\text { Time frame post- } \\
\text { transplantation }\end{array}$ & Suggested tnvestigations \\
\hline $0-2$ years & $\begin{array}{l}\text { Ultrasound every } 3 \text { months alternating with abdominal CT every } 6 \text { months } \\
\text { Chest x-ray every } 3 \text { months } \\
\text { Laboratory investigations every } 3 \text { months }\end{array}$ \\
\hline $2-5$ years & $\begin{array}{l}\text { Ultrasound every } 6 \text { months alternating with abdominal CT every } 12 \text { months } \\
\text { Chest x-ray every } 6 \text { months } \\
\text { Laboratory investigations every } 6 \text { months }\end{array}$ \\
\hline $5+$ years & $\begin{array}{l}\text { Ultrasound every } 12 \text { months } \\
\text { Chest x-ray every } 12 \text { months } \\
\text { Laboratory investigations every } 12 \text { months }\end{array}$ \\
\hline
\end{tabular}

CT: computed tomography. 